Given current international tensions, one may legitimately doubt our ability to think beyond political borders, much less biological ones.

But I am concerned with possible accomp lishments, not just easy ones. It seems to me that if Americans can be taught to think of their duties to the wider commuity of which they are a part, and if their notion of community can be expanded to encompass our fragile planet's other inhabitants, basic and radical changes will take place. The task is two-fold: to restore our sense of responsibility for our common life, and to expand our notion of the common to include our fellowtravelers on this blue-green ball.

The second step-expanding our notion of community-is a matter of education, and

\section{THE CALF'S PRAYER}

\section{REBECCA CHAPMAN}

Shall I be born unto this land of majestic mountains and fruited plains? io stand on eager, fragile limbs?

To breathe the spirit of life?

Oh, Mother, you are warm beside me And your milk flows sweetly.

I would not stray,

But close to you, I learn our way.

May we frolic in the soft meadow Where sun pours forth upon the grass? Together graze and linger?

Taste of the clear brook?

We gather with our kind Beneath the sheltering tree And. as twilight scents the air your loving conforts me.

Awaiting with bowed heads

The dawning of tomorrow,

In the dark we dream and pray:

tet not the hand of man take us away. ultimately of empirical demonstration. Every finding of the science of ecology reinforces our common planetary destiny, and I have no doubt that someday it will be cormion knowledge that all species "are in this together". But it is a further step to get humans to act for the common good. I agree with Bellah et. al. that to do so we must revive the submerged language of civic virtue -the republican tradition. Only with the restoration of the public polity can Americans create a humane community.

\section{Notes}

1. Robert N. Bellah, Richard Madsen, William M. Sullivan, Ann Swidler and Steven M. Tipton, Habits of the Heart: Individualism and Commitment in American Life (Berkeley: University of California Press, 1985).

\section{Ibid: 15-16. \\ 3. Ibid: 16 .}

4. Ibid.

5. Ibid.

6. Ibid: 335 .

Finally, to be consistent, the argument that benefiting from harms caused to other animals is always wrong should be applied to other parts of one's life, as much as possible. This means giving up animals and animal products for food, clothing, and so on, except when it is absolutely essential to use them. It would also require an entire reevaluation of one's relationship to nature. It means, in short, nothing less than the search for a whole new way of life. To avoid the negativism of the view that we are always in the wrong in our dealings with the environment, let this be thought of as learning to live in harmony with nature.

\title{
Notes
}

1. Peter Singer, Animal Liberation (New York: Avon Books, 1975): 7.

$$
\text { - continued to p. } 82 \text { - }
$$

